\title{
The seven demographic Spains. Inter-municipal contrasts in age structure : fertility and migration are the determining factors
}

In: Espace, populations, sociétés, 2000-3. Le vieillissement dans le monde. pp. 425-435.

Citer ce document / Cite this document :

Reques Velasco Pedro, Rodriguez Rodriguez Vicente. The seven demographic Spains. Inter-municipal contrasts in age structure : fertility and migration are the determining factors . In: Espace, populations, sociétés, 2000-3. Le vieillissement dans le monde. pp. 425-435.

http://www.persee.fr/web/revues/home/prescript/article/espos_0755-7809_2000_num_18_3_1962 


\section{Résumé}

Sept Espagne sur le plan démographique ? Contrastes de structures par âge à l'intérieur des municipalités.

La structure de la population dépend de l'ensemble des facteurs démographiques et sociaux qui agissent sur le territoire. Dans les pays développées, elle se caractérise par un important vieillissement, souvent mis en relations avec les composantes démographiques, économiques et sociales. L'auteur utilise des indicateurs à la fois synthétiques et analytiques pour répartir les communes espagnoles en sept classes selon leur degré de vieillissement. En résumé, la structure par âge de la population espagnole paraît localement très vieillie, notamment dans les campagnes et les espaces de montagne, à cause de l'émigration et de la chute de fécondité des dernières décennies. Les communes urbaines, qui ont accueilli de nombreux immigrants, lesquels viennent renforcer le groupe des adultes, sont plus jeunes mais commencent à vieillir. Les structures des communes méridionales ont traditionnellement toujours été plus jeunes, de même que les périphéries métropolitaines qui accueillent des jeunes couples en provenance des aires urbaines centrales.

\section{Abstract}

Population structure is considered to be a consequence of the demographic and socio-economic factors having acted in the territory, some intensely some weakly. In developed societies ageing emerges as the more outstanding phenomenon relating to the demographic, economic and social concerns. To analyse population structure in Spain at a municipal scale some indicators, both synthetic and analytic, are used to determine the assignment of each municipality to seven classes ranged from the younger to the old and very old. As a summary, the degree of ageing in Spain at municipal scale is high, mainly in rural and mountainous zones, due to the high rates of emigration and the decline of fertility in the last decades. Urban municipalities, that received immigration, rejuvenated and reinforced the adult group, are clearly becoming older. The younger demographic structures are traditionally found in southern Spain and also in the periphery of the metropolitan areas where emigrants are moving from central cities.

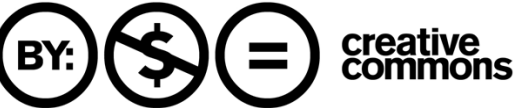


Pedro REQUES VELASCO

Vicente RODRIGUEZ RODRIGUEZ
Department of Geography, Urbanism

and Territorial Planning

University of Cantabria

Avda. De los Castros s/n

39005 Santander

Espagne

Requesp(aunican.es
Institute of Economics and Geography Consejo Superior de Investigaciones Cientificas Pinar 25

28006 Madrid

Espagne

Rodri(aieg.csic.es

\section{The seven demographic Spains Inter-municipal contrasts in age structure : fertility and migration are the determining factors}

\section{INTRODUCTION}

In geo-demographic studies, analyzing the age structure of the population is of great interest because its basic features can be understood as the consequence of the demographic and socioeconomic factors which have acted historically in each territory.

At the municipal and provincial scales, which we analyse, demographic factors have a very direct influence : some act very intensely (e.g. migration), others more weakly (e.g. fertility), and still others (e.g. mortality) have a marginal influence. In addition there are social, economic and territorial conditioning factors which have an indirect influence, such as economic dynamism, differences in welfare levels, inequalities in employment opportunitics, etc.

Thus, a variety of phenomena and factors explain and determine the great contrasts revealed by the map of Spain's demograph- ic structures, when depicted on the municipal (Map 2) or even on the provincial (Map 1) scale. The aims of this work are to highlight these contrasts and gain insight into the underlying causes.

In Geography population is always a dependent variable. Therefore, despite its great importance, it should not be examined in isolation ; otherwise, we could lose sight of its ultimate significance, which is to provide us with clues about the social and territorial processes and the factors which are explaining the differences and changes in its structure.

The shown maps will focus our attention not only on demographic features but also on underlying factors of an economic, social and territorial nature which are, in the final analysis, the determining factors.

The map on a provincial scale and the one on a municipal scale have an abridged char- 


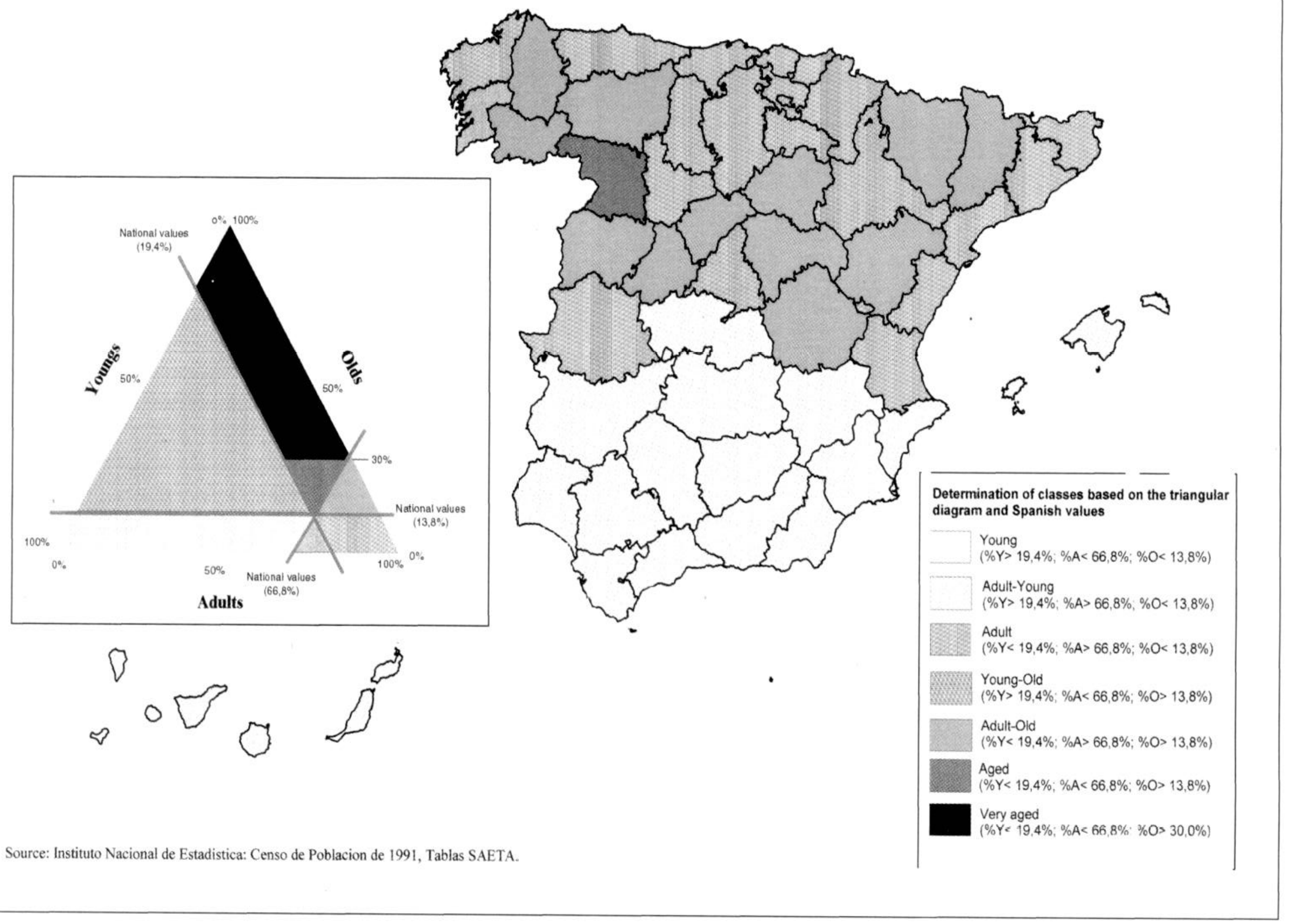




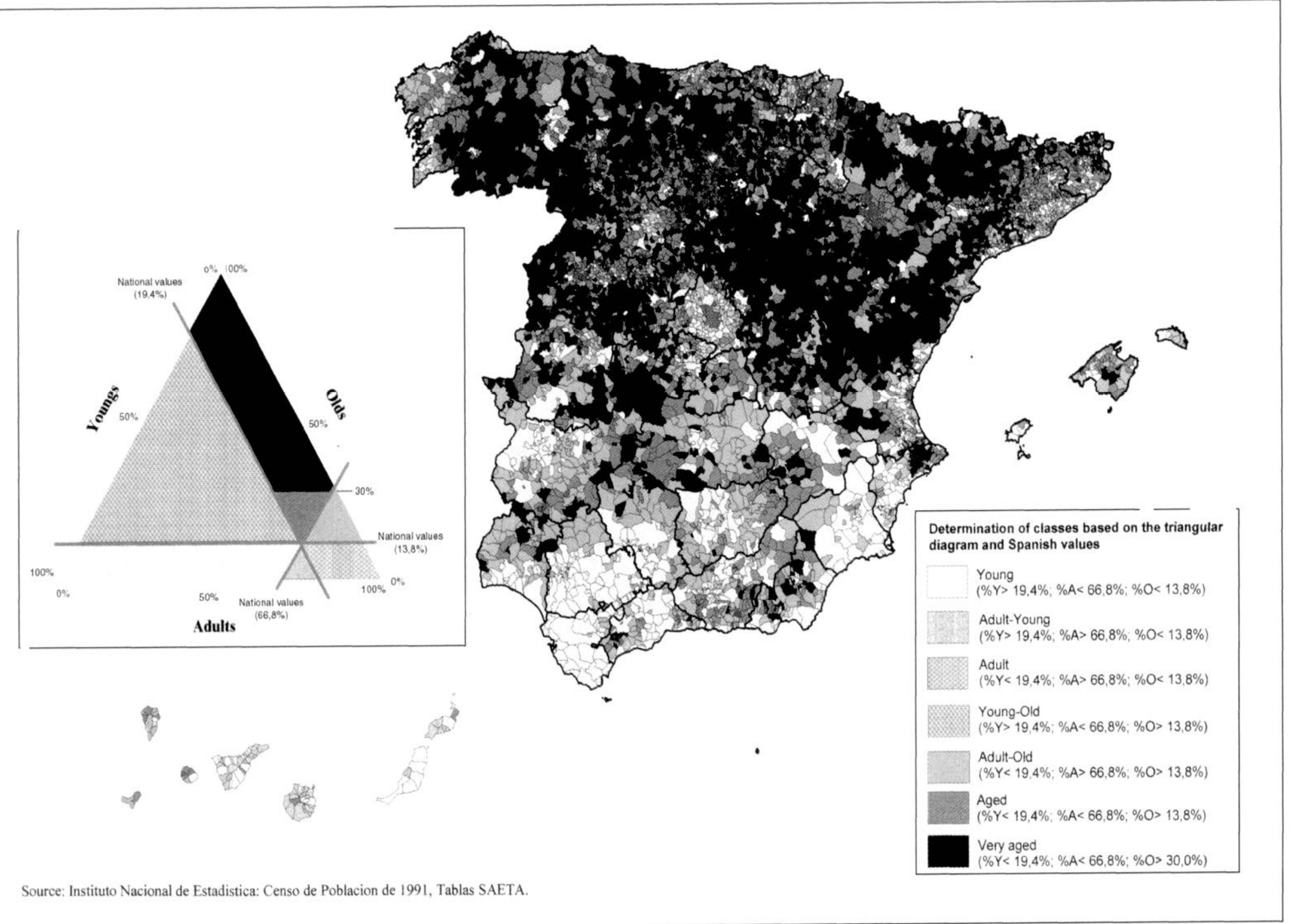


acter since they summarize all the structural indicators, both synthetic and analytic, as they were presented in Chapter IV of Atlas de la Población Española. These indicators include the following : sex ratio, proportion of old people, the old age index, proportion of young people, the dependency ratio, the replacement index, the mean age and the general structure indicator.

\section{Methods : using the triangular diagram and the national mean values to distin- guish and group municipalities}

We have made use of a triangular diagram, or ternary graph, to determine the assignment of each municipality to one of seven classes. The classification was made in relation with the national means and was based on the proportional distribution of the population in the three following large age groups : young people (0-14 years), adults (15-64) and old people (65 and over).

The ternary graph elaborated in this way allows us to define the following seven groups of municipalities, where comparisons are always with respect to the national means. Municipalities, or provinces, with a larger proportion of young people (Y) and a smaller proportion of old people $(\mathrm{O})$. (Type $1:>\% \mathrm{Y} ;<\% \mathrm{~A} ;<\% \mathrm{O})$

Municipalities, or provinces, with a larger proportion of young people and adults (A), and a smaller proportion of old people. (Type $2:>\% \mathrm{Y} ;>\% \mathrm{~A} ;<\% \mathrm{O}$ )

Municipalities, or provinces, with a larger proportion of adults, and a smaller proportion of young people and old people. (Type $3:<\% \mathrm{Y} ;>\% \mathrm{~A} ;<\% \mathrm{O})$

Municipalities, or provinces, with a larger proportion of young peoplc and old people, and a smaller proportion of adults, which are shown in gray on the map. (Type $4:>\% \mathrm{Y}$; $<\% \mathrm{~A} ;>\% \mathrm{O}$ )

Municipalities, or provinces, with a larger proportion of adults and old people, and a smaller proportion of young people. (Type 5: $<\% \mathrm{Y} ;>\% \mathrm{~A} ;>\% \mathrm{O}$ )

Municipalities, or provinces, with a larger proportion of old people, and a smaller proportion of adults and young people. (Type 6: $<\% \mathrm{Y} ;<\% \mathrm{~A} ;>\% \mathrm{O})$. Since this group of aged municipalities was the most numerous, due to the great relative weight of small administrative units, we decided to divide it into two subgroups: the aged and the very aged. The proportion of $30 \%$ of old people was taken as the threshold value to distinguish between these two subgroups. (Type $7:<\% \mathrm{Y} ;<\% \mathrm{~A} ;>>\% \mathrm{O})$

\section{The seven demographic Spains : fertility and migration as explanatory factors}

In terms of geographic surface area (Fig 2a and Map 2) it can be seen that Spain presents a high degree of aging. Practically rural Spain is relatively aged. The rural areas, mainly the mountainous zones, show marked aging, in both the base and the mid portions of the age pyramid. This has resulted in a sharp decline in gross birth rates - not necessarily in the fertility - and a progressive fall in the cohorts of children. The high degree of aging of these municipalities and provinces is due to the high rates of emigration that the rural areas experienced during the stage of economic development in the 60's and to the resulting deficit of adults, particularly young adults. This emigration took place during the 1950's, 60's and early 70's and was motivated by economic causes linked to opposing productive and spatial forces which demographically had positive effects on the urban areas (immigration, growth, rejuvenation of the population, reinforcement of the group of adults) and negative effects on the rural areas (emigration, depopulation, and loss of demographic vitality).

Moreover, there was an over-emigration of women, which led to artificially high rates of celibacy among young adults. This phenomenon tended to reinforce the decline in fertility mentioned above. As a consequence, the proportion of the population over 65 (more than the absolute numbers) increased dramatically.

The aging of the population due to the increase in life expectancy was superimposed on these three phenomena, although this factor had less structural importance.

The four demographic phenomena we have discussed briefly (migration, fall in fertility, high celibacy rates and increase in life expectancy) have brought about a crisis in the demographic structure of these areas, resulting in a process of constant depopulation, slowed only by biological exhaustion. 
Figure 1 Mean annual growth rates of Spanish municipalities, according to type of demographic structure (periods: 1970-81; 1981-91; and 1991-98)

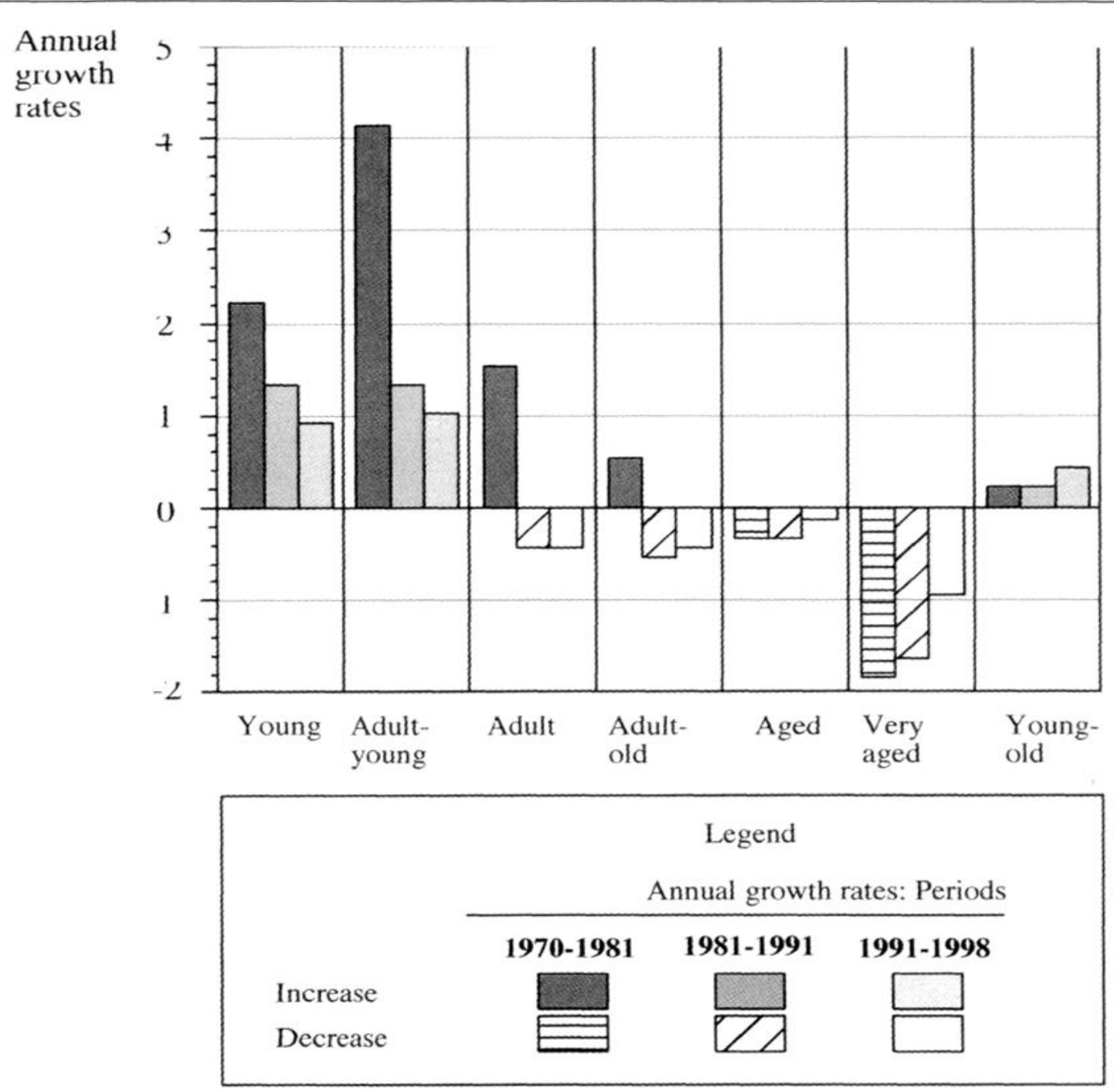

Source: INE, Censos de Población de 1970, 1981, 1991 y Padrón Municipal de Habitantes de 1996, actualizado a 1998. Elaboration: P. Reques y V. Rodríguez.

In the areas of immigration (urban areas, rural functional centers, etc.) the effect on the population has been just the opposite : reinforcement of the age groups comprising adults and adults-young people, high birth rates, relative rejuvenation of their demographic structures. These facts explain why the dominant groups in these areas are adults and young people, or both. However, the decline in fertility of the last fifteen years has affected these areas to an even greater extent that the rural areas, since these areas conform to a model of society which is more modern and evolved, with a demographic behavior typical of Western European urban societies. This explains the fact that adults are the dominant age group in many areas that have traditionally received immigration, such as the major urban centers and the central ring of the great metropolitan areas.

Map 2 offers a wealth of detailed information. We shall now discuss the main phenomena which stand out in a global analysis of this map :

a) Most of the territory of Spain shows a high degree of ageing. In terms of surface area, more than $50 \%$ of the nation's territory and almost $70 \%$ of its municipalities must be considered as aged or very aged areas (Fig. $2 a$ ).

b) A concentric structure from the city center (predominance of adults; then adults and young people; then young people) can be seen in the two major metropolitan areas, Madrid and Barcelona, and to a lesser extent 
Figure 2a : Relation between percentages of surface area and population of Spanish municipalities, according to type of demographic structure (1991)

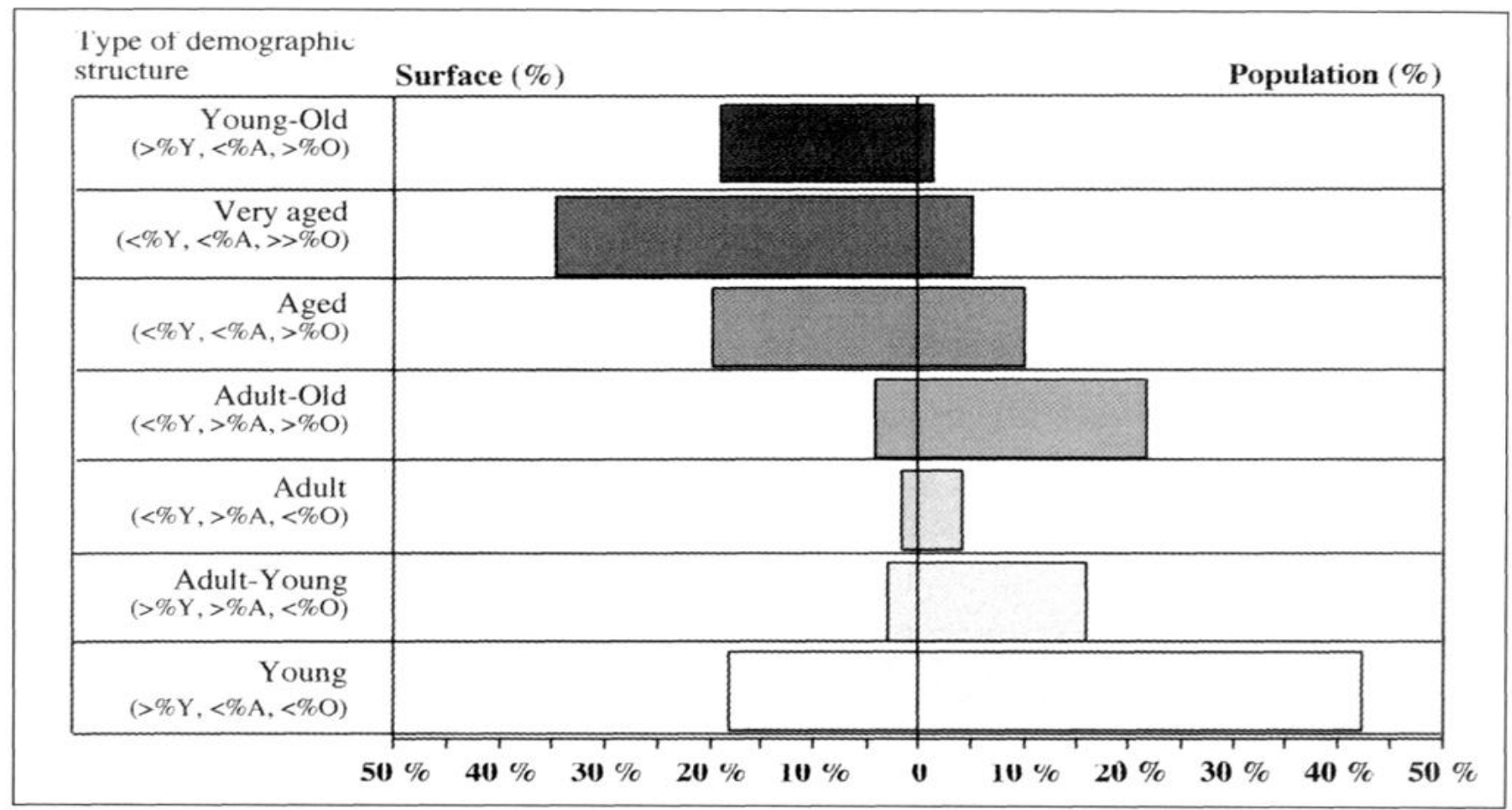

in the less important ones such as Valencia, Bilbao, etc. The city centers are dominated by adults, with the peripheral zones becoming progressively more rejuvenated.

c) There is a predominance of adults and adults-old people in the Basque Country and the northwest of Navarra. This is a consequence of the immigration of the 1950's and
60 's, of the recent fall in fertility rates and, to a lesser extent, of the net emigration of the last decade linked to return migration toward the areas of origin.

d) Clear contrasts can be seen in the demographic structures of regions like Aragón or Castilla y León, which are usually considered to be very aged. Areas that are urban,

Figure $2 b$ : Relation between percentages of municipalities and population of Spanish municipalities, according to type of demographic structure (1991)

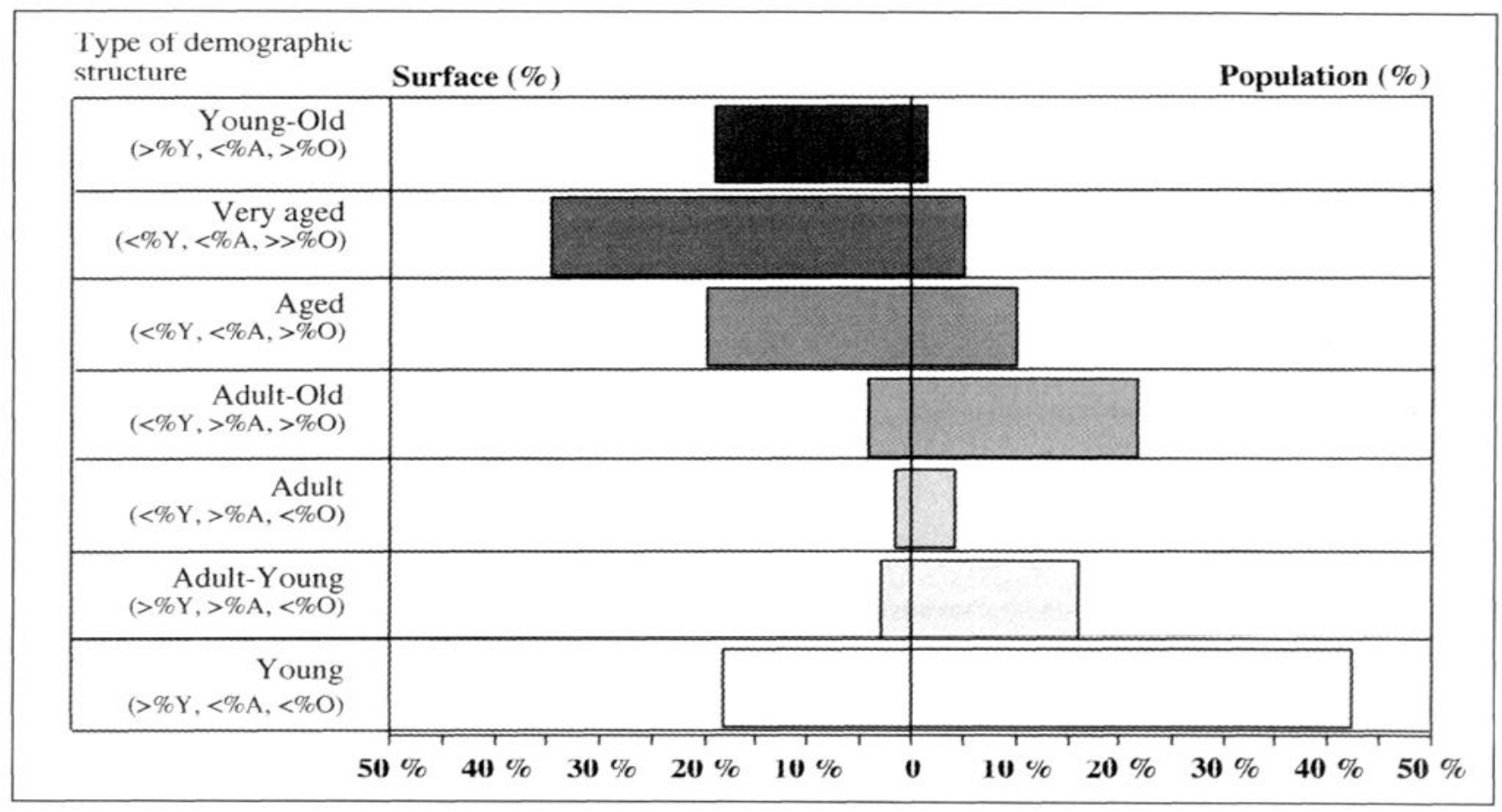


periurban or on the major axes of development, articulated by transportation routes, contrast sharply with more rural and peripheral areas, which correspond quite closely to the mountainous areas.

e) Contrasting demographic structures are also observed in regions conventionally considered to be very rejuvenated, such as the Canary Islands, where there are marked imbalances between the three western islands (Hierro, La Gomera and La Palma) and the other four (Tenerife, Gran Canaria, Lanzarote and Fuenteventura) as well as a great variety of differences within both groups. Similar observations can be made about the Baleares Islands, an insular area that is more aged but also shows sharp contrasts due to the unequal effects of urbanization, induced to a great degree by tourism.

f) Rejuvenated demographic structures are found in southern Spain, essentially in the Guadalquivir valley and the southeast of the peninsula (Alicante, Murcia and the coast of Valencia), but also in the third ring of the metropolitan areas and, in northern Spain, in the Pontevedra-Vigo axis in the Rias Bajas, in the Ferrol-La Coruña axis in the Rias Altas and, in Cantabria, in the metropolitan arch around the Bay of Santander.

Municipalities with a predominance of young people or adults and young people have been very dynamic areas with positive growth rates throughout the period 1970-98 (Fig. 1). On the other hand, there was a constant regression in the municipalities typified as adult, adult-old people, aged and very aged, except for the first two groups in the 1970's, although this regression has slowed in the last decade. It is worth noting the rapid rate of demographic decline in the very aged municipalities, which lost population at a rate of almost $2 \%$ per year in the 70's and 80's, and at an annual rate of over $1 \%$ in the 90's. It appears that this decrease in the rate of depopulation in the last decade should not be interpreted as a change in tendency but rather as proof of their high degree of demographic exhaustion.

\section{The map of young population. The vital Spain $v s$ the declining Spain}

This is a significant indicator to show the situation that has taken place in the Spanish demography in the last fifteen years because it reflects the influence of the factors such as the stabilisation of mortality rate, the backward movement of the internal migratory movements and the fall of the fertility rates. Concerning its evolution it is possible to state that 1910 acts as the year in which the percentage of young people starts to fall from a very high (30\% in 1900) to reach, already in $1991,20 \%$. In the middle, decades of the sixties and the seventies, the falling trend was reversed, influenced by the increase of the fertility rate in the sixties and seventies. After that moment, the rate went down more rapidly.

When we consider the geographical distribution, three outstanding factors arise as the main contributors to differentiate young $v s$. old areas in Spain : fertility rate, municipality size, taking into account only the amount of people living in there, and urban mobility process as occurring towards the medium and high cities and province capitals.

Taking the municipality size as the leading geographical factor, a general rule can be established as this : the larger the municipal size, the bigger the amount of young people is. So,

- rural municipalities go down to $15 \%$ as a consequence of a very deep tradition of emigration having caused a severe process of young and adult exhaustion and ageing - the medium size urban and metropolitan cities display young people percentages higher than $20 \%$, as they were the receivers of the immigrants who came from rural areas during the sixties and seventies, they increased the fertility rate and now a household formation process is occurring, being involved by the babyboomers, who are moving away from the inner cities to settle in the suburban municipalities and capital cities

- population is getting older in the inner cities, because the process already mentioned : the young households need a residential relocation, as they are "forced" by the very expensive prices of dwellings.

The geographical distribution can be explained as a clear north-south divide, or the young vs. old Spain, when we draw a west-east line crossing the Madrid province (Map 3)

- southern Spain can be considered as the youngest region as a whole, mostly over 


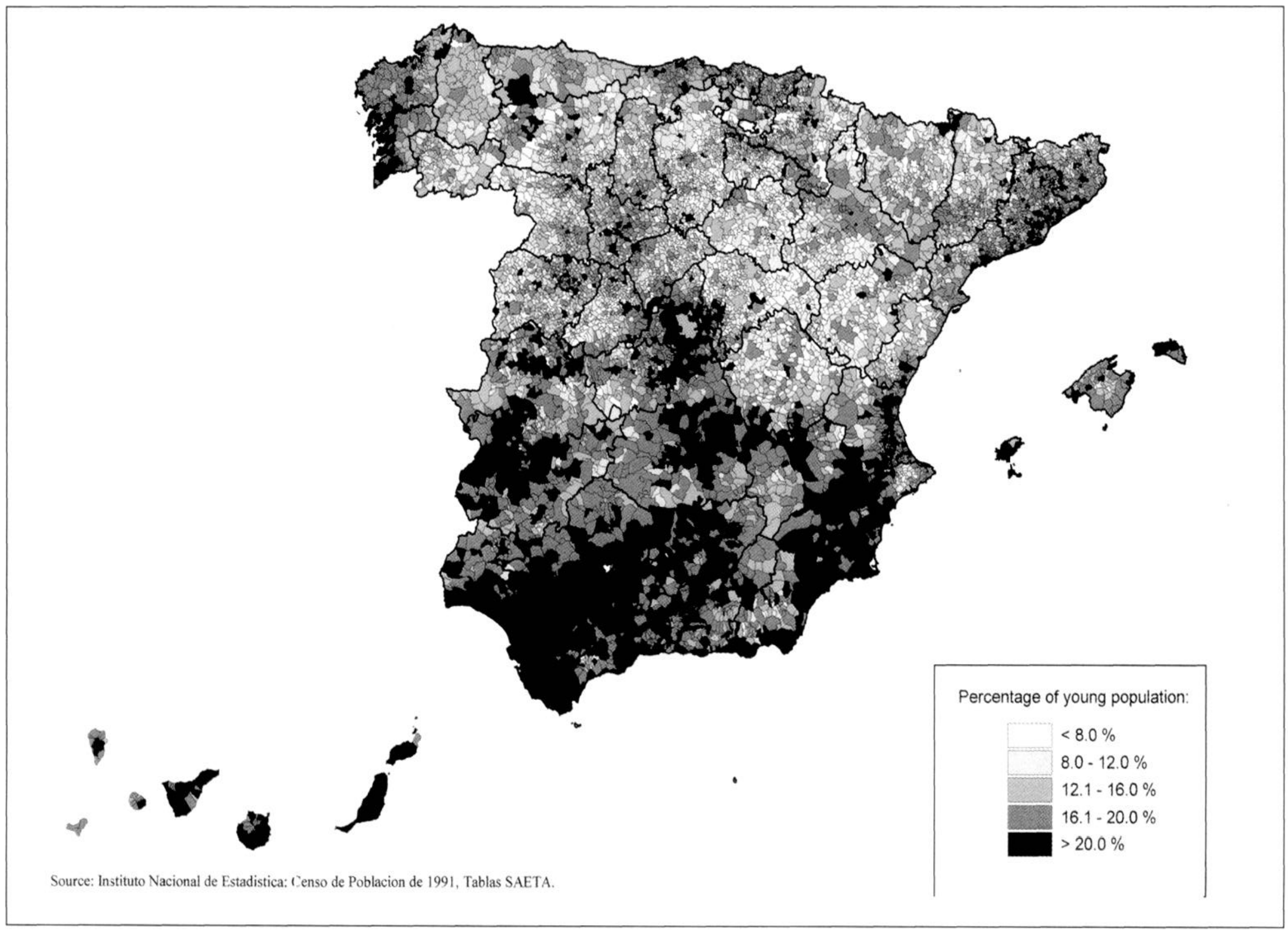

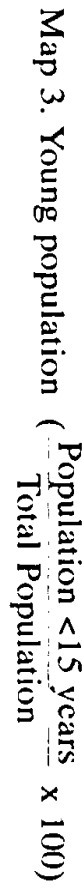




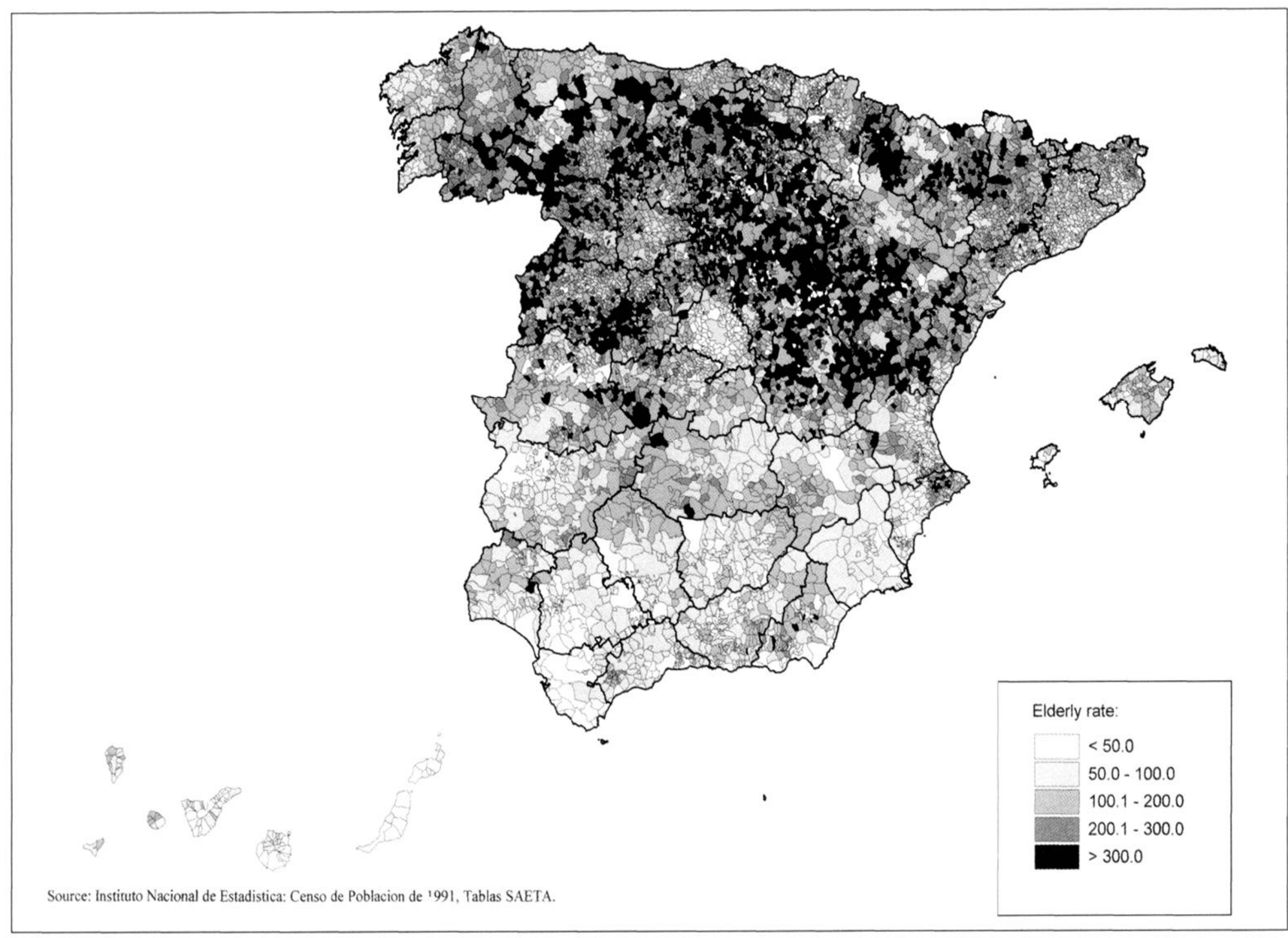


$20 \%$, but paying attention to the exceptions marked by the ranges lining the Andalusian and Castilian border with Extremadura (Sierra Morena, Montes de Toledo) and by the inner unspoiled areas (Alpujarras, eastern Baetic ranges)

- northern Spain is the stated oldest part, where the young people only account sixteen of every hundred inhabitants: the ranges crossing the North Meseta and other peripheral (Portuguese border) and mountains regions (Spanish Pyrenees, Galician and Leon ranges) are the less young regions creating a sharp contrast with Catalan coast line, the Ebro valley, the Cantabrian and Galician coast, even with some small urban and economically significant spaces surrounding Valladolid, Salamanca and el Bierzo area.

\section{The map of elderly rate. The weight of the mountain areas}

As a general hypothesis, it can be stated that the low figures of the elderly rates (Map 4) are indicating the best conditions for a young structure not only at the moment, but also at the medium term, acting this population as a base for a more equilibrated demographic structure and economic activity, running all the other conditions well. On the opposite side the high values, when old people are twice or three times bigger than the young counterparts, refer to an exhausted and aged demographic structure where the economic and welfare levels are depending in Spain on external resources and allowances for the elderly. The future will become doubtful as the time goes by.

The average elderly rate is 71 and is affecting to a very huge amount of small-sized and rural municipalities, when considering this measured at municipal level indicator. Since 1900 , this has changed at a very slow speed, but 1981 means the starting point to a faster trend until now (44 to 71 ). The last decade is considered to be as the period where Spain has became as one of the oldest countries in Europe.

From a geographical point of view, the general rule is that the size of the municipality is connected with the distribution of elderly people in the Spanish municipalities, so the larger the municipal size is the lower the older people rate is and vice versa :

- municipalities smaller than 2,000 inhabitants show a very high rate, but the total amount of elderly people as a whole is very low in comparison with those living in the cities

- cities bigger than 500,000 have reached a situation where both the elderly rates and the amount of elderly people are more important than the medium sized cities (an elderly rate lower than the Spanish average) : the demographic structure is moving fast towards an adult and old age composition, "ejecting" young people.

\section{CONCLUSION}

The municipal and provincial maps of structural typology show us a Spain with sharp contrasts in the distribution of its population by ages, and therefore a Spain with clearly differentiated demographic prospects. These demographic data must be taken into account when planning and making policies about land use, economic policy, infrastructures and facilities, and social services. Any policy that does not take this important differentiating factor into consideration is predestined to fail. 


\section{REFERENCES}

BIELZA DE ORY, V. (coord.) (1989), Territorio y Sociedad en España II. Geografia Humana, Madrid, Ed. Taurus.

CABRÉ, A., MORENO, J. Y PUJADAS, I. (1985), Cambio migratorio y reconversión territorial en España, Revista Española de Investigaciones Sociológicas, $\mathrm{n}^{2}$ 32, pp. 43-65.

CABRÉ, A., PUJADAS, I. y DEVOLDER, D. (1987), Cambios recientes en las migraciones interiores en España, Papers de demografía, $\mathrm{n}^{2} 25$, Centro d' Estudis Demográfics.

CALVO, J.L., PUEYO, A. y JOVER ,J.M. (1991), Potenciales demográficos, Atlas Nacional de España, Madrid, Instituto Geográfico Nacional, 24 p.

CALVO, J.L., PUEYO, A. y CAMPOS, A. (1993), Mapa de España en representación volumétrica de doble constricción. Población por municipios (1991). Escala 1/1.250.000, Geographicalia, n 30, pp. 59-68+ mapa.

CAMARERO, L.A. (1993), Del éxodo rural y del éxodo urbano. Ocaso y renacimiento de los asentamientos rurales en España. Madrid, MAPA.

CARRERAS, C. y GARCíA BALLESTEROS, A. (1994), Geografía de España, Barcelona, OcéanoInstituto Gallach, tomo II.

DELGADO PÉREZ, M. (1987), El reciente descenso de la fecundidad en España : un análisis por provincias,. I Congreso Hispaño-Luso-Italiano de demografía histórica, Barcelona pp. 18-32.

FERRER, M. (1988), Las nuevas tendencias de crecimiento regional, urbano y rural, Situación, $\mathrm{n}^{2} 3$, pp. 78116.

GARCIA BARBANCHO, A. y CABEZA, M. (1988), Los movimientos migratorios inter-regionales en España desde 1960, Papeles de Economía Española, $\mathrm{n}^{\circ}$ 34, pp. 24()$-267$.

GARCÍA COLL, A. y PUJADAS, I. (1996), Migraciones interiores en España : tendencias recientes y perspectivas de futuro, Revista de Geografia de la Universidad de Barcelona, v. XXIX, $\mathrm{n}^{2} 3$ (monográfico).

GARCÍA COLL, A. y SÁNCHEZ AGUILERA, M.D. (1997), Población y tamaño municipal, Estudios Geográficos, Tomo LVIII, n. 229, pp. 593-623.

GARCía FERNÁNDEZ, P. (1985), Población de los actuales términos municipales, 1900-1981. Poblaciones de hecho según los censos. Madrid, INE, 2.34 p.

FERRER, M. y CALVO, J.J. (1994), Declive demográfico, cambio urbano y crisis rural, Pamplona, EUNSA, $249 \mathrm{p}$.

Geografía de España (1989). Geografía Humana I, Barcelona, Ed. Planeta.

LÓPEZ JIMÉNEZ, J.J. (1991), Envejecimiento, tamaño demográfico y sector de actividad en los municipios españoles, Estudios Territoriales, $n^{\circ}$. 36, pp. 163-182.
MARCHENA, M. y HERNÁNDEZ, E. (1992), El mapa autonómico español : hacia el ajuste territorial, en Algunas cuestiones de Ordenación del Territorio, Alicante, Instituto Universitario de Geografía, Universidad de Alicante, pp. $111-140$.

MÉNDEZ, R. y MOLINERO, F. (1993) (coord.), Geografía de España. Barcelona, Ariel.

MORENO JIMÉNEZ, A. (1987), Concentración de la población y jerarquía de los asentamientos en España. Evolución y perspectivas, Estudios Territoriales, $\mathrm{n}^{\circ}$. 24. pp. 77-108.

OLANO REY, A. (1986), La caída actual de la fecundidad : tendencia secular o fluctuación?, in Tendencias demográficas y Planificación, Madrid, Ministerio de Economía y Hacienda, pp. 77-86.

OLIVERA, A. y VINUESA, J. (1989), La evolución del terciario en España, 1960-1985, in El desarrollo de la la población española, Madrid, Síntesis.

PUYOL ANTOLÍN, R. (1996), La población, Madrid, Ed. Síntesis ( $2^{\text {a edición). }}$

REQUES VELASCO, P. (1997), El envejecimiento de la población : una perspectiva geo-demográfico, in $\mathrm{D}$. Crespo (ed.), El envejecimiento, Philadelfia-Prons Science, Barcelona pp 1-31.

REQUES, P. (1998), Compilación de los principales indicadores analíticos y sintéticos ligados a al estructura de la población, in A. Justicio Segovia, Aportaciones a los Modelos Cuantitativos en Geografia, Depto. de geografia de la Universidad de Málaga y Grupo de Métodos Cuantitativos de la A.G.E., pp. $145-160$.

REQUES, P. (1998), Estadística y cartografía temática en Geografía de la población : fundamentos de demografía espacial, in A. Justicio Segovia, Aportaciones a los Modelos Cuantitativos en Geografia, Depto. de geografia de la Universidad de Málaga y Grupo de Métodos Cuantitativos de la A.G.E., pp. 160-180.

REQUES, P., RODRÍGUEZ, V. (1985), Prospectivas demográficas y territoriales, Traballs de la Societat Catalana de (jeografia. Institut d'Estudis Catalans, $\mathrm{n}^{\circ}$. 41, pp. 172-223.

REQUES, P., RODRÍGUEZ, V. (1998), Atlas de la población española. Un análisis de base municipal. Santander, Universidad de Cantabria, C.S.I.C., Banco de Santander y ESRI España.

RODRÍGuEZ, V. y ROJO, F. (1989), Tipología del envejecimiento de la población española, Documentos de Trabajo, $\mathrm{n}^{2}$ 2, Instituto de Economía y Geografía Aplicadas, 20 p. + ancxos.

ROUlEAU, B. (1991), Méthodes de la Cartographie, París, Presses Universitaires de France.

VÁZQUEZ BARQUERO. A. (1986), El cambio del modelo de desarrollo regional y los nuevos procesos de difusión en España, Estudios Territoriales, n. 20, pp. 87-110. 